\title{
Pengembangan Media Pembelajaran Berbasis Augmented Reality (AR) pada Materi Prosedur Penyimpanan Arsip
}

\author{
Lifa Farida Panduwinata ${ }^{1]}$, Ruri Nurul Aeni Wulandari ${ }^{2]}$, \\ Mokhammad Nurrudin Zanky ${ }^{3}$ \\ ${ }^{1,2}$ Universitas Negeri Surabaya, \\ ${ }^{3}$ Universitas Negeri Malang \\ E-mail: 1] lifapanduwinata@unesa.ac.id \\ ${ }^{2]}$ ruriwulandari@unesa.ac.id \\ ${ }^{3]}$ zanky.fe@um.ac.id
}

\begin{abstract}
Abstrak
Informasi menjadi salah satu kebutuhan yang mendasar dan sumber pengetahuan bagi setiap orang di era modernisasi seperti saat ini dan arsip merupakan salah satu sumber informasi. Fungsi kearsipan menjadi semakin penting pada saat ini karena arsip merupakan alat bukti akuntabilitas sebuah organisasi. Berdasarkan hasil pengamatan, selama ini yang terjadi dilapangan peserta didik mengalamai kesulitan dalam memahami materi prosedur penyimpanan arsip. Tujuan dari penelitian ini adalah menggabungkan Augmented Reality $(A R)$ ke dalam proses pembelajaran sebagai media pembelajaran, sehingga diharapkan dapat memberikan pengalaman belajar kepada peserta didik tentang konsep atau gagasan abstrak yang mungkin sulit dipahami oleh peserta didik. Dengan menggunakan media pembelajaran ini diharapkan peserta didik akan lebih mudah memahami prosedur penyimpanan arsip. Metode yang digunakan dalam pengembangan media pembelajaran ini adalah Multimedia Development Life Cycle (MDLC) yang bersumber dari Luther dan sudah dimodifikasi oleh Sutopo. Pengembangan media pembelajaran berbasis Augmented Reality (AR) diawali dengan pembuatan konsep, pembuatan desain, pembuatan video animasi, dan pengujian media terkait dengan kemampuan kamera telepon pintar mendeteksi overlays. Berdasarkan hasil pengembangan dan pengujian terhadap media pembelajaran berbasis Augmented Reality (AR) pada materi prosedur penyimpanan arsip dapat dikatakan berhasil. Hal ini sesuai dengan yang diharapkan yaitu untuk mempertajam pengetahuan peserta didik dalam memahami prosedur penyimpanan arip sehingga lebih mudah dalam mempraktikkan sistem penyimpanan arsip.
\end{abstract}

Kata Kunci: Pengembangan, Media Pembelajaran, Augmented Reality (AR)

\section{Learning Media Development \\ Based on Augmented Reality (AR) on Archive Storage Procedure Material}

\begin{abstract}
Information is one of the basic needs and sources of knowledge for any organization in this modern era, and archives are one source of information. The function of archiving is becoming increasingly important today because archives are evidence of the accountability of an organization. Based on the results of observations, so far what happened in the field students experienced difficulties in understanding the material for archive storage procedures. The purpose of this study is to incorporate Augmented Reality (AR) into the learning process as a learning medium, so that it is expected to provide learning experiences to students about abstract concepts or ideas that may be difficult for students to understand. By using this learning media, it is hoped that students will find it easier to understand the procedures for storing archives. The method used in the development of this learning media is the Multimedia Development Life Cycle $(M D L C)$ sourced from Luther and has been modified by Sutopo. The development of Augmented Reality (AR) based learning media
\end{abstract}


begins with conceptual creation, design creation, animation video creation, and media testing regarding the smartphone camera's ability to detect overlays. Based on the results of the development and testing of learning media based on Augmented Reality (AR) on the archive storage procedure material, it can be said to be successful. This is in accordance with what is expected, namely sharpening student knowledge in understanding archive storage procedures so that it is easier to practice the archive storage system.

Keywords: Development, Learning Media, Augmented Reality (AR)

\section{PENDAHULUAN}

Dalam menjalankan aktivitas kegiatan sehari-hari kita tidak terlepas dari yang namanya informasi untuk menambah pengetahuan dan wawasan, bahkan untuk mengambil sebuah keputusan. Informasi dapat kita ibaratkan seperti nafas yang terus berhembus disetiap waktu dan tempat. Informasi dapat kita peroleh dari orang lain, rekan kerja, social media, surat kabar, televisi, arsip dan media lainnya. Informasi yang bersumber dari arsip, dapat menghindarkan salah komunikasi, mencegah adanya duplikasi pekerjaan dan membantu mencapai efisien kerja (Sulistyo, 2013). Arsip merupakan salah satu sumber informasi yang sangat penting dalam menunjang proses kegiatan organisasi baik swasta maupun instansi pemerintah.

Fungsi arsip sebagai sumber informasi merupakan tulang punggung bagi organisasi dalam menyajikan sebuah informasi yang dapat dipertanggungjawabkan, selain itu arsip juga merupakan sarana evaluasi dalam proses penyelenggaraan kegiatan organisasi. Karena fungsi arsip sangat penting bagi suatu organisasi, maka harus dikelolah secara baik dan benar dengan menggunakan sistem kearsipan. Hal ini dimaksudkan supaya informasi yang terkandung didalamnya tetap terjaga keautentikannya seperti yang telah diamanatkan dalam Undang-undang Republik Indonesia Nomor 43 Tahun 2009 tentang Kearsipan Bab 2 Pasal 3 bagian $\mathrm{F}$ dapat tercapai yakni
"Untuk menjamin keamanan dan keselamatan arsip sebagai bukti pertanggungjawaban dalam kehidupan bermasyarakat, berbangsa dan bernegara. Dalam rangka pelaksanaan kegiatan termaksud, maka arsip mempunyai arti yang sangat penting, yaitu untuk menyusun rencana program pelaksanaan kegiatan berikutnya. Karena dengan arsip, dapat diketahui berbagai macam informasi yang sudah dimiliki, maka kita dapat menerima informasi yang terkandung di dalamnya, sehingga ditentukan sasaran yang akan dicapai dengan menggunakan potensi yang ada secara maksimal.

Arsip juga merupakan sumber ingatan bagi organisasi, oleh karena itu semua organisasi dituntut agar dapat melakukan pengelolaan arsip yang baik. Jika arsip yang dimiliki oleh suatu organisasi kurang baik pengelolaannya, maka dapat mempengaruhi tingkat reputasi organisasi tersebut, sehingga akibatnya dapat mengalami hambatan dalam pencapaian tujuan. Maksud dari arsip dikatakan sebagai sumber ingatan bagi suatu organisasi adalah karena arsip merangkul beraneka ragam bahan informasi dan bila diperlukan harus dengan cepat dan tepat disajikan setiap saat dalam rangka membantu memperlancar pengambilan keputusan.

Arsip sering kali diabaikan dalam pengelolaannya karena dipandang tidak perlu disimpan dalam suatu sistem, sehingga dapat menyebabkan masalah dalam 
kearsipan. Masalah kearsipan yang sering kali dialami hamper disemua organisasi adalah tidak di temukannnya kembali arsip ketika dibutuhkan. Di era modernisasi seperti sekarang ini arsip merupakan sumber informasi yang menjadi kebutuhan pokok bagi setiap organisasi, karena informasi menjadi sumber pengetahuan di setiap sendi kehidupan masyarakat. Tidak ditemukannya arsip ini bisa terjadi karena yang pertama petugas arsip tidak memandang penting sebuah arsip. Kedua kesalahan dalam memilih sistem penyimpanan arsip, sehingga sistem yang digunakan tidak sesuai dengan karakteristik organisasi dan arsip yang disimpan. Ketiga, karena ketidakpahaman petugas arsip mengenai prosedur penyimpanan arsip yang harusnya diterapkan. Keempat, petugas arsip seringkali tidak memiliki bacground pendidikan terkait dengan arsip.

Masalah kearsipan ini harus dapat atasi sedini mungkin untuk menghindarkan dari permasalahan yang lebih besar. Oleh karena itu, sejak dibangku perkuliahan peserta didik harus dibekali dengan pengetahuan dan ketrampilan dalam mengelolah arsip khususnya yang terkait dengan prosedur penyimpanan arsip, sehingga ketika memasuki dunia kerja mereka sudah siap. Pembelajaran manajemen kearsipan dan praktik kearsipan merupakan matakuliah wajib bagi mahasiswa program studi Pendidikan Administrasi Perkantoran. Kegiatan pemebelajaran selama ini dilakukan menggunakan metode student center learning dengan media pembelajaran berupa buku paket dan buku praktikum.

Dalam merancang kegiatan pembelajaran seorang pendidik harus mampu mengkondisikan dan menguasai kelas dengan baik, selain itu pendidik juga dituntut harus bisa membuat suasana pembelajaran yang menyenangkan dan menarik sehingga peserta didik dapat termotivasi selama mengikuti kegiatan belajar mengajar. Kegiatan belajar mengajar yang menyenangkan dan menarik dapat diciptakan melalui inovasi pada media yang digunakan dalam pembelajaran. Daryanto (2016) menjelaskan media yang digunakan dalam pendidikan memiliki batasan yakni media digunakan sebagai alat dan bahan kegiatan pembelajran. Media pembelajaran merupakan sesuatu yang dapat menrubah lingkungan pembelajaran menjadi efektif, sehingga kegiatan belajar mengajar menjadi lebih efisien karena materi pembelajaran tidak lagi abstrak yang sulit dipahami oleh peserta didik. Media pembelajaran yang menarik merupakan salah satu alternatif untuk menarik minat dan perhatian peserta didik. Sadiman (2014) mengatakan "media pengajaran merupakan segala sesuatu yang digunakan untuk menyalurkan pesan dari pengirim ke penerima sehingga dapat merangsang pikiran, perasaan perhatian dan minat penerima sedemikian rupa sehingga proses belajar yang baik dapat terjadi”. Sedangkan menurut Arsyad (2016) "media pembelajaran merupakan komponen sumber belajar atau wahana fisik yang mendukung materi instruksional dilingkungan siswa yang dapat merangsang siswa untuk belajar". Dapat disimpulkan bahwa seorang pendidik yang berhasil dalam proses pembelajaran adalah pendidik yang mampu menyediakan media pembelajaran yang dapat merangsang atau membangkitkan minat dan motivasi belajar peserta didik.

Sudjana (2015) menjelaskan bawah fungsi media pembelajaran ada tiga, pertama sebagai alat untuk memperjelas bahan pengajaran, dalam hal ini media digunakan oleh pendidik sebagai variasi dalam 
penjelasan verbal terkait dengan bahan pengajaran. Kedua, sebagai alat untuk menimbulkan persoalan yang akan dipecahkan oleh siswa dalam proses pembelajaran. Ketiga, sebagai sumber belajar bagi peserta didik, yang artinya media pembelajaran berisi bahan-bahan yang haris dipelajari oleh peserta didik baik secara individu maupun kelompok. Sementara Gerlach \& Ely dalam (Daryanto, 2016) menjelaskan fungsi media pembelajaran secara umum ada tiga yakn: 1) untuk memperkuat kemampuan fiksatif, dengan kemampuan ini pembelajaran dapat digambar atau direkam kemudian disimpan dan ketika diperlukan dapat ditampilkan seperti kejadian aslinya; 2) untuk memperkuat kemampuan manipulatif yang artinya media pembelajaran dapat menampilkan kembali objek dengan berbagai macam perubahan sesuai dengan kebutuhan pembelajaran ; dan 3) untuk memperkuat kemampuan distributif, media dapat menjangkau audiens dalam jumlah besar secara serempak dalam satu kali penayangan.

Media pembelajaran dimaksudkan untuk membantu peserta didik dalam mencapai tujuan pembelajaran. Oleh karena itu dalam memilih media pembelajaran harus disesuaikan dengan tujuan pembelajaran supaya dapat memberikan manfaat yang maksimal. Wibawanto (2017) yang menyatakan bahwa manfaat yang dimiliki media pembelajaran yakni: a) Kesulitan-kesulitan yang terjadi saat pembelajaran dapat diatasi serta memperjelas materi yang sulit dipahami; b) Dalam hal pemahaman peserta didik akan dipermudah serta dapat menjadikan kegiatan pembelajaran lebih hidup dan menarik; c) Merangsang serta menggerakkan naluri peserta didik untuk berkemauan keras dalam belajar memahami sesuatu; d)
Terciptanya kebiasaan, kemampuan dalam berpendapat (opini), memperhatikan dan memikirkan suatu pelajaran; e) Memperkuat daya ingat, perasaan serta kecepatan peserta didik dalam belajar dapat diperluas, dilatih dan juga dipertajam (kaitannya dengan indera).

Seels dan Rickey (dalam Arsyad, 2013) menyatakan bahwa seiring berkembangnya teknologi, maka diikuti pula oleh perkembangan media pembelajaran, dimana menurut mereka media pembelajaran dikategorikan menjadi empat macam yaitu: 1) Media cetak, diataranya LKS atau LKPD, teks book, modul, majalah, hand-out, dan sebagainya; 2) Media audio-visual, diantaranya proyektor, televisi, video, dan sebagainya; 3) Media dengan basis komputer, serta 4) Media gabungan beberapa media, seperti teleconference, realitas maya (virtual reality). Sedangkan Seels \& Glasgow dalam Sutirman (2013) mengemukakan ada dua macam media yakni media dengan teknologi tradisional dan media dengan teknologi mutakhir (modern). Media pembelajaran berbasis multimedia merupakan contoh dari media pembelajaran mutakhir (modern). (Munir, 2013) Multimedia merupakan perpaduan antara berbagai media (format file) yang berupa teks, gambar, grafik, sound, animasi, video, dan lain-lain yang telah dikemas menjadi file digital (komputerisasi) yang digunakan untuk menyampaikan pesan kepada publik.

Sejalan dengan perkembangan teknologi informasi saat ini, media pembelajaran juga harus mengikuti perkembangan untuk memenuhi kebutuhan peserta didik dalam mendapatkan informasi dan pendidikan yang berkualitas. Media pembelajaran yang menarik diharapakan dapat membangkitkan minat dan motivasi peserta didik 
dalam mempelajari prosedur penyimpanan arsip, sehingga peserta didik dapat memperoleh pengetahuan dan keterampilan sesuai dengan tujuan pembelajaran. Salah satu teknologi yang dapat dimanfaatkan dalam proses pembelajaran saat ini adalah Augmented Reality (AR) sebagai upaya untuk memenuhi pembelajaran yang berkembang di abad 21. Augmented Reality (AR) adalah sebuah teknologi yang menggabungkan benda maya dua dimensi ataupun tiga dimensi ke dalam lingkungan nyata lalu memproyeksikannya dalam waktu nyata (real-time) (Riyanto dan Singgih, 2015). Augmented Reality $(A R)$ sering juga disebut dengan realitas tertambah, karena teknologi Augmented Reality (AR) ini menjaga dunia nyata tetap terpusat dengan menambahkan detail digital yang lainnya. Kombinasi dari teknologi ini memungkinkan penggabungan secara (real-time) antara konten virtual pada computer/Smartphone dengan tampilan langsung melalui video.

Penggunaan media Augmented Reality $(A R)$ ini membantu pendidik dan peserta didik dalam melakukan kegiatan pembelajaran. Buku teks yang semula hanya berisi tulisan dan gambar sesuai dengan materi pembelajaran yang bersifat konvensional akan dilengkapi dengan marker (penanda) berupa gambar sebagai alat untuk melakukan tracing setelah marker (penanda) dideteksi oleh kamera, sehingga di atas marker (penanda) akan memunculkan gambar atau video yang seolah-olah nyata. Ahmadi (2017) menggunakan Augmented Reality (AR) untuk mengajarakan gerakan shalat pada siswa sekolah dasar. Teknologi Augmented Reality (AR) juga digunakan sebagai media pembelajaran teknik digital yang berupa modul praktikum dengan menggunakan Leybold Kit berupa papan trainer Leybold beserta gerbang-gerbang logika (Elisa,2014). Sedangkan Sigit (2014) menggunakan teknologi Augmented Reality $(A R)$ sebagai sarana pembelajaran interaktif bagi siswa Sekolah Dasar Berbasis Android pada materi tata surya. Setyawan (2019) menggunakan Augmented Reality (AR) pada pembelajaran IPA siswa sekolah dasar. Mustaqim dan Kurniawan (2017) juga menggunakan Augmented Reality (AR) sebagai media pembelajaran interaktif yang menyenangkan dan memotivasi siswa untuk mengembangkan bakat, minat serta kreativitas dan kemandirian dalam belajar bagi siswa SMK, dikarenakan dalam pembelajaran SMK lebih mengutamakan praktikum dari pada teori. Selain itu penggunaan media Augmented Reality (AR) terbukti dapat meningkatakan hasil belajar siswa, khususnya untuk pelajaran biologi pada materi sistem pencernaan (Mauludin, 2017). Dari beberapa hasil penelitian diatas dapat dikatakan bahwa teknologi Augmented Reality (AR) dapat kita gunakan sebagai pengembangan media pembelajaran.

Berdasarkan hasil pengamatan, selama ini yang terjadi dilapangan peserta didik mengalamai kesulitan dalam memahami materi prosedur penyimpanan arsip. Hal ini terlihat jelas ketika mereka mempraktikan prosedur penyimpanan arsip dengan menggunakan lima sistem penyimpanan arsip dikelas masih sering terjadi kesalahan. Hal ini terjadi dikarenakan ketika dalam pembelajaran manajemen kearsipan khususnya pada materi prosedur penyimpanan arsip peserta didik terlihat kurang antusias. Kurang antusnya peserta didik dalam mengikuti pembelajaran dikelas bisa disebabkan karena media pemelajaran yang digunakan kurang menarik, sebagai contoh pendidik 
hanya menggunakan buku teks dan power point saja dalam kegiatan belajar mengajar. Kurangnya minat peserta didik dalam kegiatan pembelajaran terlihat ketika proses pembelajaran berlangsung sering kali peserta didik tidak memperhatikan penjelasan dari dosen pengajar, terlebih untuk peserta didik yang duduk dibarisan tengah kebelakang banyak yang kedapatan sedang bermain smartphone masing-masing dan bicara sendiri dengan teman sebelahnya. Dari hasil pengamatan inilah tim pengembang akan memanfaatkan smartphone peserta didik sebagai sarana media pembelajaran, sehingga peserta didik menggunakan smartphone untuk mendukung pembelajaran bukan untuk kegiatan di luar pembelajaran. Maka tujuan dari penelitian ini adalah mengembangkan teknologi Augmented Reality (AR) sebagai media pembelajaran, sehingga diharapkan dapat memberikan pengalaman belajar kepada peserta didik tentang konsep atau gagasan abstrak yang mungkin sulit dipahami oleh peserta didik. Dengan menggunakan media pembelajaran ini diharapkan peserta didik akan lebih mudah memahami prosedur penyimpanan arsip.

\section{METODE}

Pengembangan

media pembelajaran ini menggunakan metode MDLC (Multimedia Development Life Cycle) dari Luther yang dimodifikasi oleh Sutopo (2003). Metodologi pengembangan multimedia ini terdiri dari enam tahap yaitu concept (konsep), design (desain), Material collecting (pengumpulan materi), assembly (pembuatan), testing (pengujian), dan distribution (distribusi).

Concept merupakan tahapan pertama yang digunakan untuk mengidentifikasi pengguna, sehingga tujuan dari pengembangan media ini jelas dan tepat sasaran. Design merupakan tahapan kedua yang membuat storyboard untuk mendeskripsikan tiap scene serta memasukkan semua objek multimedia kedalam scene. Material Collecting merupakan tahap ketiga yang berupa pengumpulan data yang diperlukan. Data tersebut, dapat berupa gambar, clip art, foto, animasi, video, dan audio. Assembly merupakan tahapan keempat berupa pembuatan semua objek atau bahan dan data multimedia. Aplikasi dibuat berdasarkan pada design, storyboard, dan bagan alir serta stuktur navigasi. Testing merupakan tahapan yang kelima berupa pengujian alpha (alpha test), dan tahapan yang terakhir yaitu Distribuiton, berupa penyaluran aplikasi media pembelajaran kepada pengguna (mahasiswa) dengan media internet. Tahapan pengembangan multimedia ini dapat digambarkan sebagai berikut:

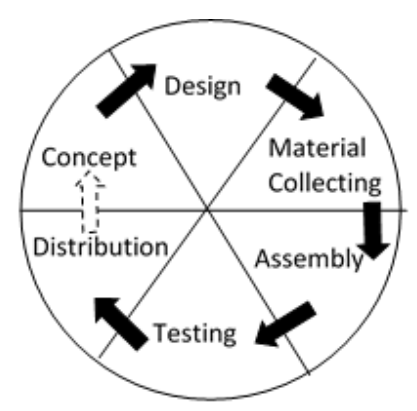

Gambar 1. Model Pengembangan Multimedia Luther-Sutopo, 2003

\section{Sumber: Binanto (2010)}

\section{a. Concept (konsep)}

Tahapan awal pada pengembangan multimedia ini yaitu pembuatan konsep. Pada tahapan ini tim pengembang menentukan tujuan dari pengembangan, menentukan siapa yang akan menjadi audiens (pengguna), termasuk jenis dan bentuk aplikasi yang akan 
diembangkan. Aplikasi yang di buat dalam penembangan ini berupa media pembelajaran pada mata kuliah Manajemen Kearsipan dengan materi prosedur penyimpanan arsip yang memanfaatkan teknologi Augmented Reality (AR). Media pembelajaran ini bertujuan untuk mendukung proses pembelajaran di kelas selain menggunakan buku teks dan power point yang selama ini digunakan.

\section{b. Design (Perancangan) \\ Pada tahapan perancangan tim pengembang membuat} spesifikasi secara rinci terkait dengan aplikasi yang akan dikembangkan, mulai dari menetukan tim pembuat aplikasi, menentuka matareial yang akan digunakan sesuai dengan materi pembelajaran, menentukan diagram alur dan membuat storyboard. Dalam tahapan ini dilakukan pembuatan model peralatan dan perlengkapan penyimpanan arsip dalam bentuk video animasi. Selain itu, pada tahapan perancangan ini dibuat storyboard prosedur penyimpanan arsip yang menggambarkan deskripsi tiap scenenya.

\section{c. Material Collecting (pengumpulan materi) \\ Dalam tahap ini yang} dilakukan tim pengembang adalah menggumpulkan bahan berupa gambar, foto, video, dan materi yang diperlukan dalam membuat media pembelajaran berbasis Augmented Reality prosedur penyimpanan arsip.

\section{d. Assembly (pembuatan)}

Dalam tahapan ini yang dikerjakan adalah pembuatan objek yang berupa video animasi oleh pihak jasa pembuat sesuai dengan tahapan perancangan yang telah dirancang oleh tim pengembang. Pada tahapan ini, selain membuat video animasi juga memasukan video animasi tersebut kedalam aplikasi AR.

\section{e. Testing (pengujian)}

Pada tahapan pengujian ini dilakukan setelah tahap pembuatan untuk melihat apakah terdapat kesalahan atau error pada aplikasi yang telah dibuat. Selain itu juga akan dilakukan uji validasi kepada ahli media untuk memastikan apakah media tersebut sudah layak atau masih perlu untuk dilakukan revisi. Fungsi dari tahapan ini untuk melihat apakah hasil dari aplikasi yang telah dibuat sesuai dengan harapan atau belum.

\section{f. Distribuiton (distribusi)}

Pada tahap pendistribusian ini dilakukan pada tahapan paling akhir yaitu ketika aplikasi media pembelajaran ini dinyatakan layak untuk digunakan dan sesuai dengan yang diharapkan. makaaplikasi kepada peserta didik. Tahapan ini dilakuan pendistribusian media pembelajaran berbasis Augmented Reality $(A R)$ melalui bantuan internet kepada seluruh peserta didik yang menempuh mata kuliah Manajemen Kearsipan.

Dari enam tahapan pengembangan multimedia ini dalam praktiknya tidak harus dilakukan secara berurutan, kecuali untuk tahapan concept harus dilakukan ditahapan pertama dan tahapan pendistribusian dilakukan terakhir (Binanto, 2010).

\section{HASIL DAN PEMBAHASAN}

Pengembangan media pembelajaran berbasis Augmented Reality $(A R)$ akan diterapakan pada mata kuliah manajemen kearsipan khususnya pada materi prosedur penyimpanan arsip. Pengembangan media pemebelajaran ini diawali dengan membuat konsep, yang bertujuan untuk mendukung proses pembelajaran di kelas yang selama ini 
hanya menggunakan media power point dan buku teks. Hal ini dilakukan untuk mempertajam pengetahuan peserta didik dalam memahami prosedur penyimpanan arsip sehingga memudahkan mereka dalam praktik kearsipan. Tahapan selanjutnya adalah tahap perancangan atau pembuatan desain dimana tim pengembang menuangkan detail rancangan dalam bentuk storyboard prosedur penyimpanan arsip yang menggambarkan deskripsi tiap scenenya. Setelah storyboard selesai dibuat dilanjutkan dengan membuat video animasi yang dilakukan oleh tim jasa pembuat video animasi sesuai dengan arahan dari tim pengembang.

Sebelum media pembelajaran berbasis Augmented Reality (AR) pada materi prosedur penyimpanan arsip didistribusikan ke peserta didik maka dilakukan uji validasi oleh ahlih media untuk memastikan bahwa media pembelajaran tersebut layak untuk digunakan. Selain melakukan uji validasi juga dilakukan pengujian untuk menemukan penyebab kamera gagal mendeteksi simbol overlays yang menyebabkan objek video animasi tidak dapat muncul pada layar smartphone. Kegagalan kamera dalam mendeteksi simbol overlays ini kemungkinan terjadi akibat dari faktor lingkungan antara lain cahaya dan jarak kamera terhadap simbol overlays.

Kemampuan kamera dalam mendeteksi simbol overlays dipengaruhi oleh cahaya, oleh karenanya dilakukan pengujian pada beberapa tempat yang berbeda penerangannya. Pengujian pertama dilakukan dengan intensitas cahaya yang sangat rendah di dalam ruangan yang tidak menggunakan lampu atau penerangan. Selain itu pengujian juga dilakukan didalam ruangan dengan penerangan untuk intensitas cahaya rendah. Pengujian kedua dilakukan pada siang hari diluar ruangan ketika matahari tepat berada diatas kepala kita dan tidak berawan dengan intensitas cahaya tinggi, pada pengujian kedua ini juga dilakukan pada pagi dan sore hari ketika intensitas cahaya lebih rendah. Aplikasi yang digunakan untuk mengukur intensitas cahaya adalah "Lux Light Meter" yang dapat diunduh di Goggle Play Store.

\section{A. Hasil Pengujian Pertama}

Dari hasil pengujian pertama terhadap kemapuan kamera mendeteksi simbol overlays untuk dapat menampilakan video animasi prosedur penyimpanan arsip yang dipengaruhi oleh cahaya dan jarak dengan menggunakan aplikasi " $L u x$ Light Meter" adalah sebagai berikut:

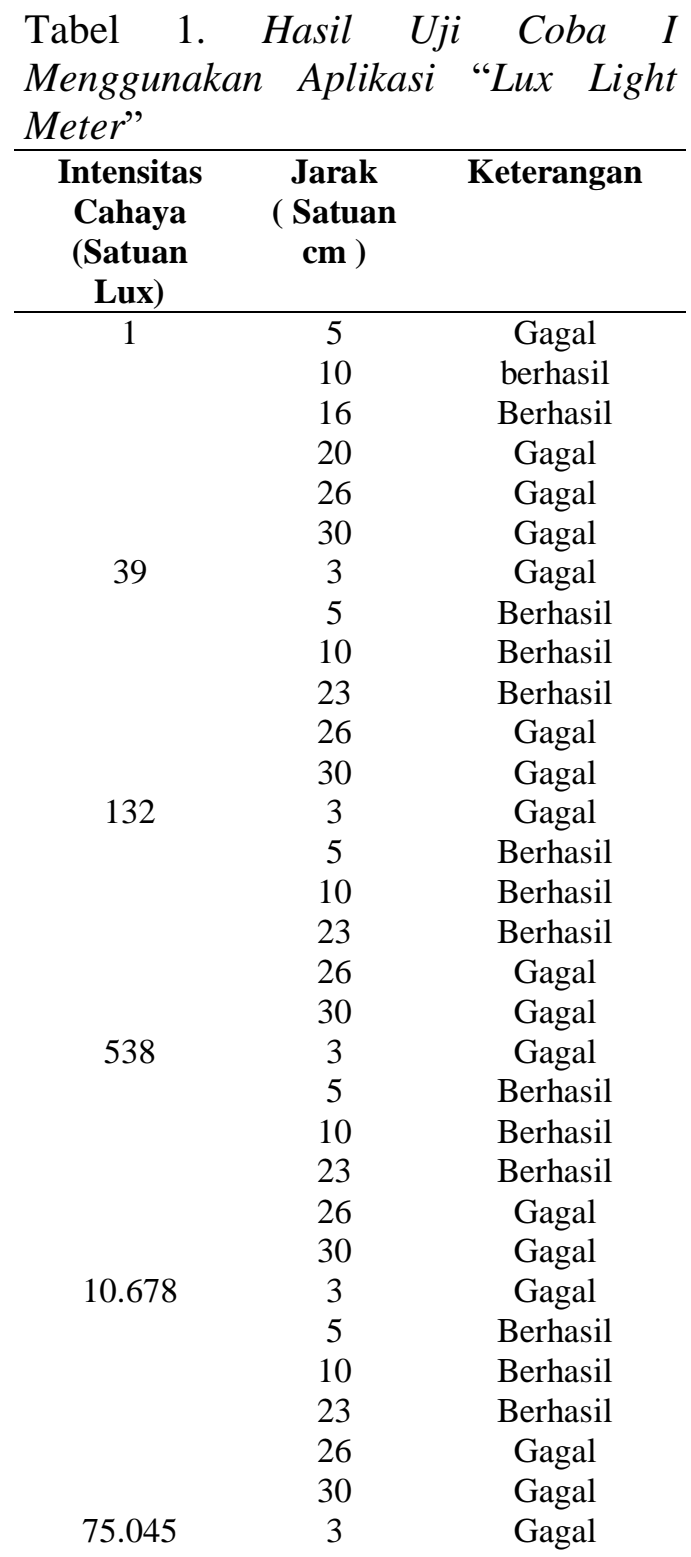




\begin{tabular}{cc}
5 & Berhasil \\
10 & Berhasil \\
23 & Berhasil \\
26 & Gagal \\
30 & Gagal \\
\hline
\end{tabular}

Dari Tabel 1 di atas dapat diketahui bahwa dengan intensitas cahaya yang sangat rendah kamera gagal mendeteksi simbol overlays apabila jarak terlalu dekat yaitu kurang dari $6 \mathrm{~cm}$ dan jarak terlalu jauh yaitu lebih dari $20 \mathrm{~cm}$. Pada intensitas cahaya rendah kamera gagal mendeteksi simbol overlays dengan jarak kurang dari $3 \mathrm{~cm}$ dan lebih dari $26 \mathrm{~cm}$. Sama halnya dengan intensitas cahaya sedang hingga tinggi kamera juga gagal mendeteksi simbol overlays dengan jarak kurang dari $3 \mathrm{~cm}$ dan lebih dari $26 \mathrm{~cm}$. Dari hasil pengujian pertama dapat disimpulkan bahwa jarak antara kamera dengan simbol overlays yang lebih berpengaruh kepada kemampuan kamera dalam mendeteksi simbol overlays dibandingkan dengan intensitas cahaya. Karena kamera tetap dapat mendeteksi simbol overlays walau intensitas cahaya sangat rendah sekalipun, begitu pula dengan intensitas cahaya yang sangat tinggi kamera tetap dapat mendeteksi simbol overlays.

Dari hasil pengujian pertama juga diketahui bahwa pendeteksian simbol overlays masih belum bisa fokus hanya pada simbol overlays saja. Hal ini di ketahui ketika kamera digunakan untuk mendeteksi simbol overlays dengan jarak kurang dari 5 $\mathrm{cm}$.

\section{B. Revisi Produk}

Dari beberapa kekurangan hasil pengujian pertama, maka perlu dilakukan revisi terhadap simbol overlays. Simbol overlays sendiri merupakan simbol atau marker (penanda) yang digunakan untuk menampilkan video pembelajaran prosedur penyimpanan arsip yang teradapat dalam buku ajar prosedur penyimpanan arsip. Simbol overlays inilah yang disebut dengan simbol Augmented Reality (AR).

Pembuatan simbol overlays dikerjakan oleh tim jasa pembuat yang diarahkan dan diawasi oleh tim pengembang. Pada awalnya tim jasa pembuat hanya diminta untuk membuatkan simbol khusus terkait dengan kata-kata tertentu yang diberikan oleh tim pengembang. Misalnya kata "mensortir surat", maka kata itu dijadikan acuan oleh tim jasa pembuat untuk membuat simbol.

Setelah seluruh simbol overlays dibuat oleh tim jasa pembuat, kemudian simbol overlays tersebut oleh tim pengembang dimasukkan ke dalam aplikasi HP Reveal yang berbarsis Augmented Reality (AR) akan tetapi simbol tersebut tidak dapat dibuat overlays. HP Reveal merepakan sebua aplikasi yang sebelumnya dinamakan Aurasma, dimana aplikasi ini digunakan untuk belajar Augmented Reality menggunakan objek berupa gambar, foto, kartu nama sebagai marker (penanda) untuk menampilkan obyek berupa gambar ataupun video animasi. Sebuah simbol atau marker tidak dapat dibuat overlays dikarenakan tingkat keunikan dari simbol tersebut masih sederhana berdasarkan pengujian menggunakan aplikasi HP Reveal. Kesederhanaan ini ditunjukkan oleh tanda merah yang terdapat dalam aplikasi HP Reveal ketika digunakan untuk mendeteksi simbol overlays seperti ditunjukkan dalam gambar berikut:

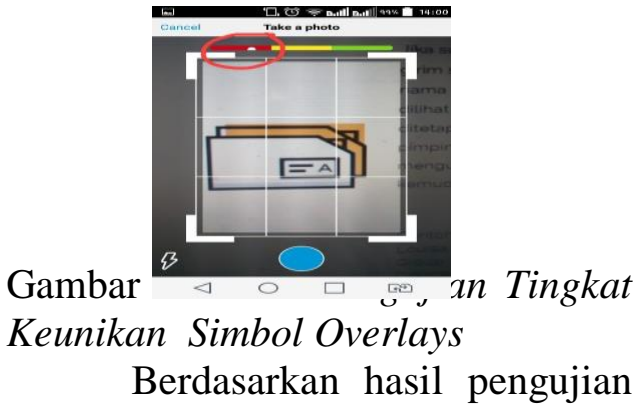


simbol overlays dengan menggunakan aplikasi HP Reveal yang terlihat pada gambar 2 di atas, tim pengembang meminta tim jasa pembuat untuk membuat simbol overlays menjadi lebih unik lagi. Selain membuat simbol menjadi lebih unik juga dilakukan revisi terkait penggunaan warna pada simbol overlays. Setelah dilakukan revisi terhadap simbol, maka tim pengembang melakukan pengujian sekali lagi terhadap simbol overlays. Setelah direvisi seluruh simbol overlays yang digunakan oleh tim pengembang sudah sesuai dengan ketentuan yang terdapat dalam aplikasi HP Reveal, yaitu seluruh simbol sudah berwarna hijau seperti yang ditunjukkan dalam gambar 3 yang berarti simbol overlays sudah memiliki tingkat keunikan yang lebih tinggi dibandingkan sebelum direvisi.

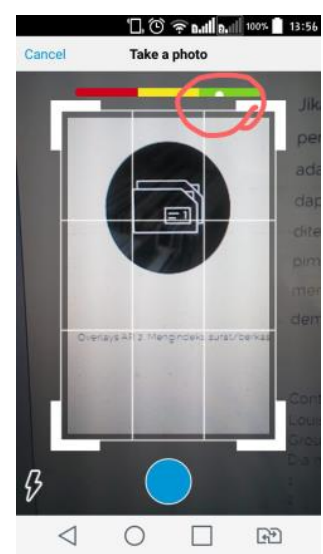

Gambar 3. Hasil Pengujian Tingkat Keunikan Simbol Overlays Setelah Direvisi

\section{Hasil Pengujian Kedua}

Hasil pengujian kedua ini lebih difokuskan pada tingkat pencahayaan yang dibutuhkan untuk membaca simbol overlays. Hal ini terkait dengan penggunaan warna dan tingkat keunikan yang terdapat dalam simbol overlays. Adapun hasil dari pengujian kedua dengan menggunakan aplikasi "Lux Light Meter" untuk mengetahui pengaruh cahaya dan jarak tergambarkan dalam tabel berikut:

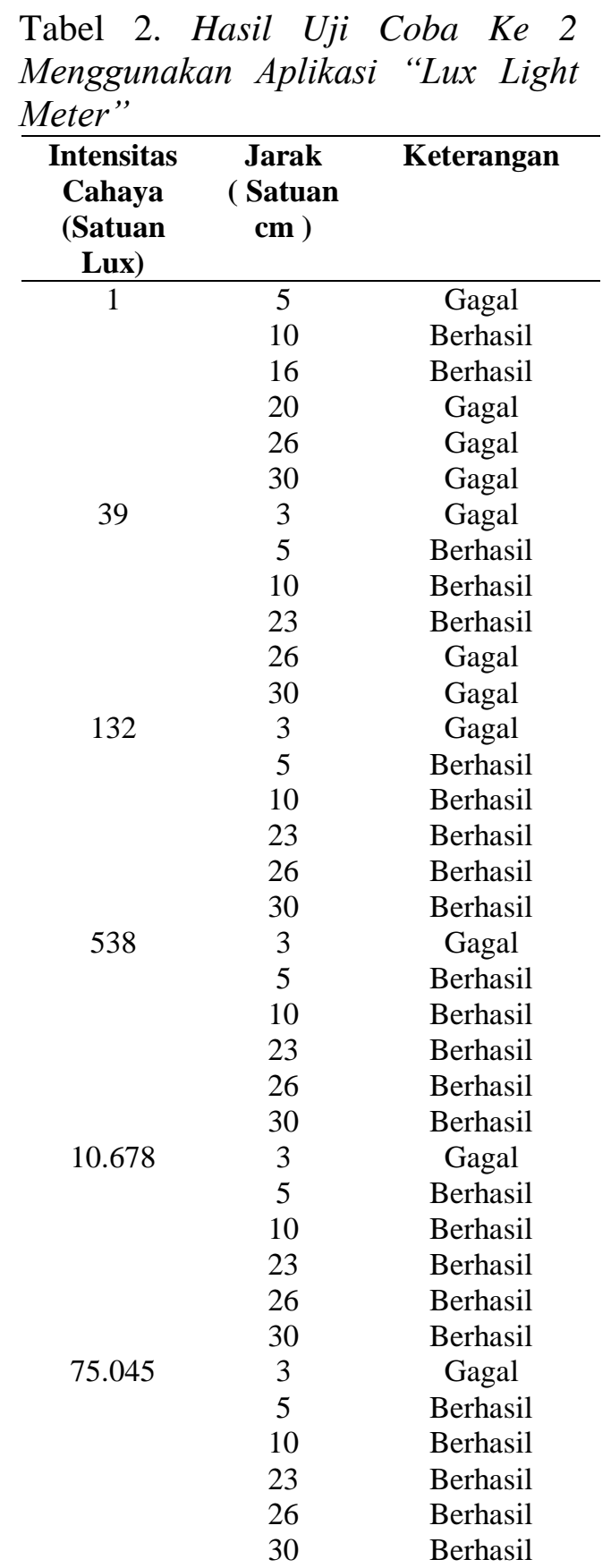

Dari tabel 2 di atas dapat di ketahui bahwa dengan intensitas cahaya yang sangat rendah kamera tidak dapat mendeteksi simbo overlays dengan jarak kurang dari 5 $\mathrm{cm}$ dan jarak lebi dari $20 \mathrm{~cm}$. Pada intensitas cahaya rendah kamera tidak dapat mendeteksi simbol overlays dengan jarak kurang dari $3 \mathrm{~cm}$ dan lebih dari $26 \mathrm{~cm}$. Sedangkan untuk intesitas cahaya sedang hingga sanggat tinggi kamera tidak dapat mendeteksi simbol overlays dengan jarak kurang dari $3 \mathrm{~cm}$ dan masih 
dapat mendeteksi simbol dengan jarak lebih dari $30 \mathrm{~cm}$. Jadi kesimpulan dari pengujian kedua ini untuk intensitas cahaya sangat rendah tidak ada perubahan dari kemampuan kamera dalam mendeteksi simbol overlays baik pada jarak kurang dari $5 \mathrm{~cm}$ maupun pada jarak lebih dari $20 \mathrm{~cm}$. Sama halnya dengan penggunaan intensitas cahaya rendah juga tidak terdapat perbedaan antara pengujian pertama dengan pengujian yang kedua. Sedangkan untuk intensitas cahaya sedang hingga sanggat tinggi untuk jarak kurang dari $3 \mathrm{~cm}$ kamera tetap tidak dapat mendeteksi simbol overlays sama seperti yang terjadi pada pengujian pertama, akan tetapi untuk jarak lebih dari $30 \mathrm{~cm}$ pada pengujian kedua ini kamera dapat mendeteksi simbol overlays dan pada pengujian yang pertama kamera hanya mampu mendeteksi sampai pada jarak $26 \mathrm{~cm}$. Selain itu pada pengujian kedua ini pendeteksian simbol overlays juga lebih fokus dibandingkan pada pengujian pertama sebelum terjadi revisi produk (simbol overlays).

Setelah media pembelajaran berbasis Augmented Reality (AR) ini selesai dibuat dan dilakukan pengujian sebanyak dua kali baik terkait dengan keunikan simbol overlays maupun kemampuan kamera dalam mendeteksi simbol overlays yang dipengaruhi oleh cahaya dan jarak. Langkah selanjutnya sebelum mendistribusikan media pembelajaran pada peserta didik adalah melakukan validasi oleh ahli media. Validasi ahli media ini dilakukan untuk melihat kelayakan dari media pembelajaran tersebut digunakan dalam proses belajar mengajar. Hasil validasi ahli media ini adalah terkait dengan adanya beberapa video animasi yang perlu di perjelas, sehingga dilakukan proses perbaikan video animasi prosedur penyimpanan arsip oleh tim jasa pembuat. Sedangkan untuk validasi terkait dengan materi pembelajaran yang digunakan dilakukan pada tahap pengumpualan materi (material coleecting) oleh ahli materi.

Berdasarkan

hasil pengembangan dan pengujian terhadap media pembelajaran berbasis Augmented Reality (AR) pada mata kuliah manajemen kearsipan khususnya materi prosedur penyimpanan arsip dapat dikatakan berhasil. Dapat pula dikatakan pendidik (tim pengembang) berhasil membuat media pembelajaran yang dapat menarik minat dan fokus peserta didik selama proses pembelajaran berlangsung. Terbukti ketika proses pembelajaran berlangsung peserta didik fokus terhadap penjelasan pendidik dan menggunakan smartphonenya sebagai media pembelajaran, hal ini sangat berbeda dengan sebelum menggunakan media pembelajaran berbasis Augmented Reality (AR) dimana peserta didik menggunakan smartphonenya untuk bermain game, media sosial (instagram dan tweeter), serta berbelanja online. Dengan menggunakan media pembelajaran berbasis Augmented Reality (AR) ini peserta didik lebih mudah memahami materi yang disampaikan karena peserta didik dapat langsung melihat prosedur penyimpanan arsip secara langsung melalui video animasi yang ada dalam aplikasi di smartphone masing-masing di bandingkan hanya dengan mendengar penjelasan pendidik dan membaca buku saja. Sehingga sesuai dengan yang diharapkan media pembelajaran berbasis Augmented Reality (AR) bertujuan untuk mempertajam pengetahuan peserta didik dalam memahami prosedur penyimpanan arsip sehingga lebih mudah dalam mempraktikan lima sistem penyimpanan arsip tanpa adanya kesulitan seperti sebelum menggunakan media pembelajaran ini. 
Adapun cara kerja media pembelajaran berbasis Augmented Reality (AR) prosedur penyimpanan arsip ini adalah sebagai berikut:

1. Pastikan di dalam smartphone sudah ada aplikasi HP Reveal untuk dapat menggunakan media pembelajaran berbasis Augmented Reality (AR). Aplikasi HP Reveal dapat di unduh di Google Playstore dan app store.

2. Tekan aplikasi HP Reveal dengan simbol seperti ditunjukkan dalam gambar di bawah ini.

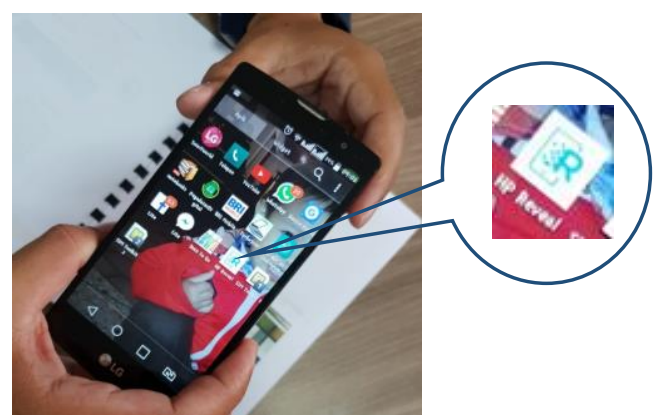

Gambar 4. Simbol Aplikasi HP Reveal

3. Setelah tekan simbol HP Reveal maka akan muncul tampilan awal Aplikasi seperti gambar di bawah ini. Tampilan awal ini kadang membutuhkan waktu beberapa saat tergantung pada spesifikasi HP yang digunakan. Tunggu sampai dengan masuk sempurna pada aplikasi

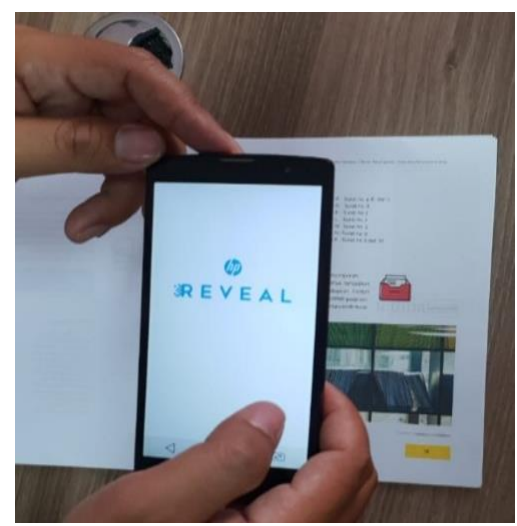

Gambar 5. Tampilan Awal Aplikasi HP Reveal
4. Untuk menjalankan deteksi pada simbol Augmented Reality (AR) tekan tombol bulat berwarna biru.

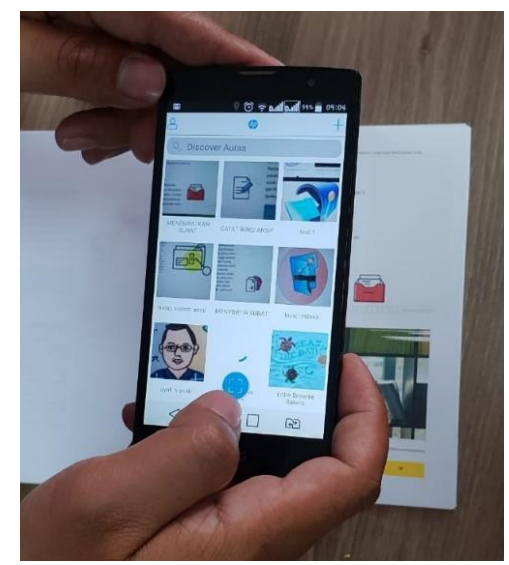

Gambar 6. Mengoperasikan Aplikasi HP Reveal

5. Fokuskan kamera pada gambar Augmented Reality (AR) sampai terasa getaran pada HP, maka secara otomatis aplikasi HP Reveal akan membaca simbol overlays tersebut yang dapat berupa video animasi atau gambar dengan tampilan lain. Jika setelah difokuskan tidak terjadi getaran atau tidak terhubung dengan gambar maka kamera agak ditarik menjauh dengan gambar. Untuk langka ini pastikan bahwa akun yang digunakan untuk membaca simbol Augmented Reality (AR) mem-follow akun channel INOBEL dari udinzanky@gmail.com.

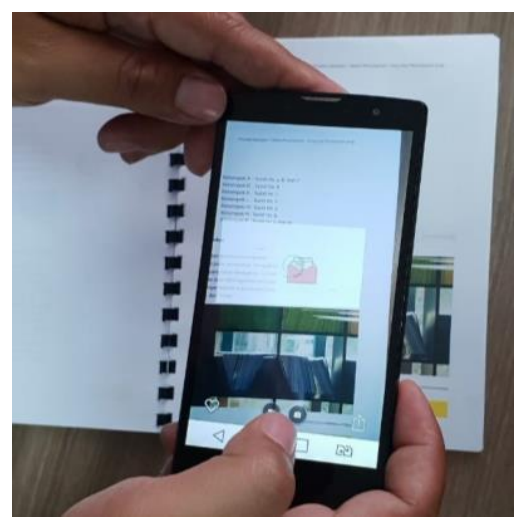

Gambar 7. Kamera mendeteksi Simbol Overlays 
Demikian langkah untuk menjalankan aplikasi HP Reveal yang berbasis Augmented Reality (AR).

\section{KESIMPULAN}

Pengembangan

Media pembelajaran berbasis Augmented Reality (AR) pada materi prosedur penyimpanan arsip ini diawali dengan membuat konsep sesuai dengan materi yang telah ditetapkan. Setelah pembuatan konsep dilanjutkan dengan pembuatan desain yang dituangkan dalam bentuk storyboard prosedur penyimpanan arsip yang menggambarkan deskripsi tiap scenenya. Berikutnya adalah pembuatan video animasi sesuai dengan storyboard dan yang terakhir melakukan pengujian media pembelajaran. Media pembelajaran berbasis Augmented Reality (AR) di lakukan pengujian menggunakan aplikasi android yang bernama "Lux Light Meter" untuk mengetahui penyebab kamera gagal mendeteksi simbol overlays yang menyebabkan objek video animasi tidak dapat muncul pada layar smartphone. Penggujian dilakukan sebanyak dua kali, pengujian pertama dilakukan dengan intesitas cahaya serendah mungkin dalam ruangan baik dengan maupun tanpa penerangan. Pengujian yang kedua dilakukan pada pagi, siang, dan sore hari diluar ruangan dengan tingkat intensitas cahaya sedang sampai tinggi. Hasil dari pengujian pertama dan kedua memperlihatkan bahwa jarak kamera terhadap simbol overlays lebih berpengaruh terhadap kemampuan kamera mendeteksi simbol overlays. Pengembangan Media ini dapat dikatakan berhasil karena dapat mempertajam pengetahuan peserta didik dalam memahami prosedur penyimpanan arsip sehingga lebih mudah dalam mempraktikkan lima sistem penyimpanan arsip.

\section{DAFTAR PUSTAKA}

Ahmadi, Re Arief, dkk. 2017. Teknologi Augmented Reality Sebagai Media Pembelajaran Gerakan Shalat. Prosiding Seminar Nasional Komputer dan Informatika (SENASKI)

Arsyad, Azhar. (2016). Media Pembelajaran. Jakarta: Raja Grafindo Persada.

Binanto, I. 2010. Multimedia Digital Dasar Teori dan Pengembangannya. Andi Offset. Yogyakarta.

Daryanto. (2016). Media Pembelajaran. Yogyakarta: Gava Media.

Elisa Usada. 2014. Rancang Bangun Modul Praktikum Teknik Digital Berbasis Mobile Augmented Reality (AR). Jurnal Infotel. 6(2). Hlm. 83-88

Mauludin, Rizqi ， dkk. 2017. Penerapan Augmented Reality Sebagai Media Pembelajaran Sistem Pencernaan pada Manusia dalam Mata Pelajaran Biologi. Jurnal Edukasi dan Penelitian Informatika (JEPIN) 3(2), 42-48

Munir. 2013. Pembelajaran Jarak Jauh Berbasis Teknologi dan Komunikasi. Bandung: CV Alfabeta.

Mustaqim, I. dan Kurniawan, N. 2017. Pengembangan Media Pembelajaran Berbasis Augmented Reality. Jurnal Edukasi Elektro 1(1), 36-48

Riyanto \& Singgih. 2015. Pemanafaatan Augmented Reality pada Media 
Pembelajaran Interaktif

Peredaran Planet. JUITA ISSN:

2086-9398 Vol III Nomor 4

November 2015

Sadiman, A.S, dkk. (2014). Media pendidikan : pengertian, pengembangan dan pemanfaatannya. Depok: PT. Raja Grafindo Persada.

Setyawan, Bintoro, dkk. 2019. Augmented Reality Dalam Pembelajaran IPA Bagi Siswa SD. Kwangsan-Jurnal Teknologi Pendidikan 07(1), 78-90

Sigit Ady P. 2014. Augmented Reality Tata Surya sebagai Sarana Pembelajaran Interaktif Bagi Siswa Sekolah Dasar Berbasis Android. Laporan Penelitian. Universitas Muhammadiyah Surakarta.

Sudjana, N, Rivai, A. (2015). Media Pengajaran. Bandung: Sinar Baru Algensindo.

Sutirman. 2013. Media \& Modelmodel Pembelajaran Inovatif. Yogyalarta: Graha Ilmu

Wibawanto, Wandah. (2017). Desain Dan Pemrograman Multimedia Pembelajaran Interaktif. Jember: Cerdas Ulet Kreatif. 